\title{
Rhodococcus pyridinivorans sp. nov., a pyridine-degrading bacterium
}

\author{
Jung-Hoon Yoon, ${ }^{1}$ Seok-Sung Kang, ${ }^{1}$ Young-Gyun Cho, ${ }^{2}$ Sung Taik Lee, ${ }^{2}$ \\ Yung Hee Kho, ${ }^{1}$ Chul-Joong $\mathrm{Kim}^{3}$ and Yong-Ha Park ${ }^{1}$
}

Author for correspondence: Yong-Ha Park. Tel: +8242860 4620. Fax: +82428604598 e-mail: yhpark@mail.kribb.re.kr

\footnotetext{
1 Korea Research Institute of Bioscience and Biotechnology (KRIBB), PO Box 115, Yusong, Taejon, Korea

2 Department of Biological Sciences, Korea Advanced Institute of Science and Technology, Taejon, Korea

3 College of Veterinary Medicine, Chungnam National University, Taejon, Korea
}

\begin{abstract}
The taxonomic position of a bacterial strain (PDB9') that is capable of degrading pyridine was clarified by a polyphasic taxonomic approach using phenotypic, chemotaxonomic and genetic methods. The cells, which are rods and branched filaments during the early growth phase, fragment into short rods or cocci, thereby completing the growth cycle. Strain PDB9' was found to have a cell wall of chemotype IV, MK-8 $\left(\mathrm{H}_{2}\right)$ as the predominant menaquinone, mycolic acids with 36-46 carbon atoms and $C_{16: 0}, C_{18: 1}$ cis9, 10-methyl- $C_{18: 0}$ (TBSA) as the major fatty acids. The G+C content of the DNA was $66 \mathrm{~mol} \%$. The phylogenetic tree showed that strain PDB9 $^{\top}$ falls within an evolutionary radiation comprising $R$ hodococcus species and is most closely related to the type strain of Rhodococcus rhodochrous, sharing $99 \% 16 \mathrm{~S}$ rDNA similarity. The differences in some phenotypic characteristics and the genetic distinctiveness distinguish strain PDB9' from the Rhodococcus species described previously. Therefore, strain PDB9' should be placed in the genus Rhodococcus as a new species, for which the new name Rhodococcus pyridinivorans sp. nov. is proposed. The type strain of the new species is strain PDB9' $\left(=\right.$ KCTC 0647BP' $^{\top}$ $=$ KCCM 80005').
\end{abstract}

Keywords: Rhodococcus pyridinivorans sp. nov., pyridine degradation, polyphasic taxonomy

\section{INTRODUCTION}

Members of the actinomycetes have been widely studied because of the biotechnological importance of some of their characteristics, such as the ability to produce various secondary metabolites. Actinomycetes are also very important in the context of bioremediation because they have considerable potential to degrade a variety of xenobiotics, including toxic aromatic compounds (Peczynska-Czoch \& Mordarski, 1984). Pyridine is one such aromatic compound found to be degradable by some actinomycete strains (Shukla \& Kaul, 1974, 1975; Watson \& Cain, 1975; Lee et al., 1994). Pyridine is used as a solvent in industry and in laboratories and is generated as a by-product of industrial activities such as coal gasification, oil-shale retorting, chemical synthesis and pharmaceutical

Abbreviation: FAME, fatty acid methyl ester.

The GenBank accession number for the 16S rDNA sequence of strain PDB9 ${ }^{\top}$ is AF173005. The GenBank accession number for the newly determined $16 \mathrm{~S}$ rDNA sequence of Rhodococcus zopfii DSM $44108^{\top}$ is AF191343. manufacture (Stuermer et al., 1982; Sims \& O'Loughlin, 1989). Pyridine also occurs in the environment as a result of the use of herbicides and insecticides in agriculture. Since pyridine is both a potential carcinogen and highly mobile through the environment because of its high degree of solubility in water, it has been known to be harmful to human health (Jori et al., 1983; Leenheer \& Stuber, 1981). Accordingly, it is very important to find useful microorganisms that have a great capacity to utilize or degrade pyridine. Bacterial strains that degrade pyridine and pyridine derivatives have been isolated in our studies and, of the isolates, some were described as being new species (Yoon et al., 1997, 2000). Recently, one strain (PDB9 ${ }^{\mathrm{T}}$ ) was found to have a strong capacity to degrade pyridine, and was considered to be a Rhodococcus-like strain. The genus Rhodococcus is a unique taxon comprising strains that are metabolically versatile (Finnerty, 1992). Many rhodococci have also been described as being able to degrade numerous aromatic compounds (Rast et al., 1980; Warhurst \& Fewson, 1994). There are few reports on Rhodococcus 
strains that are capable of degrading pyridine (Brinkmann \& Babel, 1996). The aim of the present study was to unravel the exact taxonomic status of strain PDB9 ${ }^{\mathrm{T}}$ by using a combination of polyphasic taxonomic data. We describe the morphological, physiological and chemotaxonomic characteristics, the phylogeny, based on $16 \mathrm{~S}$ rDNA sequences, and the DNA-DNA relatedness with type strains of some Rhodococcus species. On the basis of the data presented below, it is proposed that strain $\mathrm{PDB}^{\mathrm{T}}$ should be placed in the genus Rhodococcus as a new species, namely Rhodococcus pyridinivorans.

\section{METHODS}

Bacterial strains. Strain PDB9 ${ }^{T}$ was isolated by selective enrichment from an industrial wastewater in Korea. The wastewater sample was inoculated in $50 \mathrm{ml}$ minimal salts medium containing (per litre) $1 \mathrm{~g} \mathrm{~K} \mathrm{~K}_{2} \mathrm{HPO}_{4}, 0.5 \mathrm{~g}$ $\mathrm{NaH}_{2} \mathrm{PO}_{4} \cdot 2 \mathrm{H}_{2} \mathrm{O}, 0 \cdot 25 \mathrm{~g} \mathrm{KCl}, 0 \cdot 25 \mathrm{~g} \mathrm{MgSO}_{4} .7 \mathrm{H}_{2} \mathrm{O}$ and $1 \mathrm{ml}$ trace-element solution (Houghton \& Cain, 1972) supplemented with $0 \cdot 1 \%(\mathrm{v} / \mathrm{v})$ pyridine. This medium was incubated at $30^{\circ} \mathrm{C}$ on a horizontal shaker at 150 r.p.m. After being shaken for several days, a portion of the suspension was transferred into $50 \mathrm{ml}$ fresh medium and the medium was reincubated. After three successive transfers, the suspension was plated on solid media containing $0 \cdot 1 \%(\mathrm{v} / \mathrm{v})$ pyridine, to isolate pure cultures. Single colonies were tested to investigate the ability to degrade pyridine in minimal salt medium. Of the isolates, strain PDB9 ${ }^{\mathrm{T}}$, having a high level of pyridine-degrading activity, was selected for further study.

Rhodococcus rhodococcus KCTC 9086 ${ }^{\mathrm{T}}$ (= DSM 43241 ${ }^{\mathrm{T}}$ ) was obtained from the Korean Collection for Type Cultures (KCTC). The type strains of other Rhodococcus species used as reference organisms were obtained from the Deutsche Sammlung von Mikroorganismen und Zellkulturen (DSMZ).

Culture conditions. Strain $\mathrm{PDB}^{\mathrm{T}}$ was cultivated on trypticase soy agar (TSA; BBL) or trypticase soy broth (TSB; $\mathrm{BBL})$ at $30^{\circ} \mathrm{C}$ to investigate its morphological and physiological characteristics. Cell mass for the analyses of cell wall, menaquinones and mycolic acid was obtained from TSB culture. Cell mass for DNA extraction was produced on TSB supplemented with glucose $(0.75 \%, \mathrm{w} / \mathrm{v})$. All strains were cultivated at $30{ }^{\circ} \mathrm{C}$ on a horizontal shaker at 150 r.p.m., and the broth cultures were checked microscopically for purity before being harvested by centrifugation. Strain PDB9 ${ }^{\mathrm{T}}$ and some reference strains were also cultivated at $30^{\circ} \mathrm{C}$ for $6 \mathrm{~d}$ on TSA for fatty acid methyl ester (FAME) analysis.

Morphological and physiological characterization. The morphology of cells was examined by light microscopy and transmission electron microscopy. The presence or absence of flagella was determined using transmission electron microscopy with cells from exponentially growing culture, as described previously (Yoon et al., 1999). Oxidase activity was determined by oxidation of $1 \% p$-aminodimethylaniline oxalate. Catalase activity was determined by bubble formation in a $3 \%$ hydrogen peroxide solution. Urease production and hydrolyis of casein, gelatin, hypoxanthine, starch, Tween 80, tyrosine and xanthine were determined as described previously (Cowan \& Steel, 1965). Hydrolysis of arbutin was determined according to the method of Kurup \& Fink (1975). Nitrate reduction, methyl red and VogesProskauer reactions, hydrogen sulfide production and hydrolysis of aesculin were determined as described by Lanyi
(1987). Acid production from carbohydrates was determined by using the method of Hugh \& Leifson (1953). Utilization of organic acids ( $1 \%$ sodium salts) was determined as described previously (Takeuchi \& Hatano, 1998).

Isolation of DNA. Chromosomal DNA was isolated and purified according to the method described previously (Yoon et al., 1996), with the exception that ribonucelase T1 was used together with ribonuclease A.

Chemotaxonomic characterization. The isomer type of the diamino acid in the cell wall was analysed using TLC according to the method described previously (Komagata \& Suzuki, 1987). The sugars of the cell wall were analysed as described previously (Saddler et al., 1991). The acyl type of the peptidoglycan was determined by the method of Uchida \& Aida (1977). Menaquinones were analysed as described by Komagata \& Suzuki (1987), using reversed-phase HPLC. Analysis of mycolic acids was performed at the DSMZ (Germany). For quantitative analysis of cellular fatty acid compositions, a loop of cell mass was harvested and FAMEs were prepared and identified according to the instructions of the Microbial Identification System (MIDI).

Determination of $\mathbf{G}+\mathbf{C}$ content. The $\mathrm{G}+\mathrm{C}$ content of the DNA was determined by the method of Tamaoka \& Komagata (1984). DNA was hydrolysed and the resultant nucleotides were analysed by reversed-phase HPLC.

DNA-DNA hybridization. DNA-DNA hybridization was performed fluorometrically by the method of Ezaki et al. (1989), using photobiotin-labelled DNA probes and microdilution wells.

16S rDNA sequencing and phylogenetic analysis. The $16 \mathrm{~S}$ rDNA of strain PDB9 ${ }^{\mathrm{T}}$ was amplified by a PCR using two universal primers as described previously (Yoon et al., 1998). The sequencing of $16 \mathrm{~S}$ rDNA was performed as described previously (Yoon et al., 1998). The 16S rDNA sequence of strain PDB9 ${ }^{\mathrm{T}}$ was also determined by another method. The PCR product was purified using the QIAquick PCR purification kit (Qiagen). The purified 16S rDNA was sequenced using the ABI PRISM BigDye Terminator Cycle Sequencing Ready Reaction kit (Applied Biosystems) as recommended by the manufacturer. The purified sequencing reaction mixtures were electrophoresed automatically using an Applied Biosystems model 310 automatic DNA sequencer. The 16S rDNA sequence of strain PDB9 ${ }^{\mathrm{T}}$ was aligned with the 16S rRNA gene sequences of Rhodococcus species and some other related actinomycete taxa by using CLUSTAL w software (Thompson et al., 1994). The 16S rDNA similarity values were calculated from the alignment. Gaps at the 5'- and $3^{\prime}$-ends of the alignment were omitted from further analyses. Phylogenetic trees were inferred by using three tree-making algorithms, i.e. the neighbour-joining (Saitou \& Nei, 1987), maximum-likelihood (Felsenstein, 1981) and maximum-parsimony (Kluge \& Farris, 1969) methods. The PHYLIP package (Felsenstein, 1993) was used for the neighbour-joining, maximum-likelihood and maximum-parsimony analyses. Evolutionary distance matrices for the neighbour-joining method were calculated with the algorithm of Jukes \& Cantor (1969), using the DNADIST program. The stability of relationships was assessed by a bootstrap analysis of 1000 data sets, using the programs SEQBOOT, DNADIST, NEIGHBOR and CONSENSE of the PHYLIP package.

Nucleotide sequence accession numbers. The GenBank and EMBL accession numbers for the reference 16S rDNA sequences used in this analysis are as follows: $\mathrm{X} 80626$ (Rhodococcus coprophilus DSM 43347 ), X80614 (Rhodo- 
Table 1. Differential physiological characteristics of strain PDB9 ${ }^{\top}$ and the type strains of some Rhodococcus species

+ , Positive reaction; - , negative reaction; w, weakly positive reaction; ND, not determined. All strains were positive for catalase and utilization of fumarate. All strains were negative for oxidase, DNase, Voges-Proskauer and methyl red reactions, for hydrolysis of casein, hypoxanthine, starch and xanthine and for acid production from L-arabinose, D-cellobiose, D-galactose, inulin, lactose, D-raffinose and L-rhamnose.

\begin{tabular}{|c|c|c|c|c|c|c|}
\hline Characteristic & $\begin{array}{l}\text { R. coprophilus } \\
\text { DSM } 43347^{T}\end{array}$ & $\begin{array}{c}\text { R. rhodnii } \\
\text { DSM } 43336^{\mathrm{T}}\end{array}$ & $\begin{array}{l}\text { R. rhodochrous } \\
\text { KCTC } 9086^{T}\end{array}$ & $\begin{array}{c}\text { R. ruber DSM } \\
4^{43338^{T}}\end{array}$ & $\begin{array}{c}\text { R. zopfii } \\
\text { DSM } \mathbf{4 4 1 0 8}^{\mathrm{T}}\end{array}$ & $\begin{array}{l}\text { Strain } \\
\text { PDB9 }^{T}\end{array}$ \\
\hline Nitrate reduction & + & - & + & + & + & + \\
\hline Production of $\mathrm{H}_{2} \mathrm{~S}$ & + & + & - & + & - & + \\
\hline \multicolumn{7}{|l|}{ Hydrolysis of: } \\
\hline Arbutin & - & - & + & - & - & + \\
\hline Aesculin & - & - & + & - & + & + \\
\hline Tween 80 & + & - & + & + & + & + \\
\hline Tyrosine & - & + & + & + & - & + \\
\hline Urea & - & + & - & - & + & + \\
\hline \multicolumn{7}{|l|}{ Acid production from: } \\
\hline D-Fructose & + & - & + & + & - & + \\
\hline D-Glucose & $\mathrm{w}$ & + & + & + & - & - \\
\hline Glycerol & - & - & + & + & - & + \\
\hline Maltose & - & - & + & - & - & - \\
\hline D-Mannitol & - & + & + & + & - & + \\
\hline D-Mannose & + & - & + & - & - & + \\
\hline D-Ribose & - & - & - & - & $\mathrm{W}$ & + \\
\hline Salicin & - & - & + & - & - & + \\
\hline D-Sorbitol & - & + & + & + & - & + \\
\hline Starch & - & - & - & + & - & + \\
\hline Trehalose & - & - & + & - & - & - \\
\hline D-Xylose & - & $\mathrm{W}$ & - & - & - & - \\
\hline \multicolumn{7}{|l|}{ Utilization of: } \\
\hline Acetate & $\mathrm{w}$ & + & + & + & - & + \\
\hline Benzoate & + & + & + & + & + & - \\
\hline Citrate & - & - & + & + & - & + \\
\hline Succinate & - & + & + & + & + & + \\
\hline Degradation of pyridine & - & - & - & - & - & + \\
\hline Growth at $45^{\circ} \mathrm{C}^{*}$ & - & - & - & - & ND & + \\
\hline
\end{tabular}

* Data are from Goodfellow (1989).

coccus equi DSM 20307 ${ }^{\mathrm{T}}$ ), X79289 (Rhodococcus erythropolis DSM 43066 ${ }^{\mathrm{T}}$ ), X79186 (Rhodococcus fascians DSM 20669 ${ }^{\mathrm{T}}$ ), X80619 (Rhodococcus globerulus DSM 43954 $)$, X80617 (Rhodococcus marinonascens DSM 43752 ), X80630 (Rhodococcus opacus DSM 43205'), X92114 (Rhodococcus percolatus HAMBI 1752 ; Briglia et al., 1996), X80621 (Rhodococcus rhodnii DSM $43336^{\mathrm{T}}$ ), X79288 (Rhodococcus rhodochrous DSM 43241 ${ }^{\mathrm{T}}$ ), X80625 (Rhodococcus ruber DSM $43338^{\mathrm{T}}$ ), AF191343 (Rhodococcus zopfii DSM 44108 ${ }^{\mathrm{T}}$ ), X84248 (Corynebacterium diphtheriae NCTC $11397^{\mathrm{T}}$ ), X79290 (Dietzia maris DSM 43672 ${ }^{\mathrm{T}}$ ), X80635 (Gordonia amarae DSM $43392^{\mathrm{T}}$ ), X79287 (Gordonia bronchialis DSM $43247^{\mathrm{T}}$ ), X80632 (Gordonia rubropertincta DSM 43197 ${ }^{\mathrm{T}}$ ), X52917 (Mycobacterium tuberculosis; Rogall et al., 1990), X80606 (Nocardia asteroides DSM 43757 ${ }^{\mathrm{T}}$ ), X80608 (Nocardia brasiliensis DSM 43758 ${ }^{\mathrm{T}}$ ), X80611 (Nocardia otitidiscaviarum DSM 43242 ${ }^{\mathrm{T}}$ ), Z35435 (Skermania piniformis IFO $15059^{\mathrm{T}}$ ), X80628 (Tsukamurella paurometabola DSM 20162 ${ }^{\mathrm{T}}$ ) and X92981 (Tsukamurella pulmonis IMMIB D- $\left.1321^{\mathrm{T}}\right)$.

\section{RESULTS}

\section{Morphological and physiological characteristics}

Strain PDB9 ${ }^{\mathrm{T}}$ was found to be a non-spore-forming, non-motile, Gram-positive bacterium that is Gramvariable in old cultures. Substrate mycelia that are on the surface and penetrate into agar media were observed which fragment into short rod-to-coccus elements. Cells were rods and branched filaments during the early growth phase then fragmented into short rods or cocci, thereby completing the growth cycle as the culture aged. Colonies appeared light orange in colour and were opaque and raised with slightly irregular edges on TSA. Colonies has irregularly round wrinkles. Strain PDB9 ${ }^{\mathrm{T}}$ had catalase and urease activities but no oxidase or DNase activities.

Strain PDB9 $^{\mathrm{T}}$ grew well over a broad $\mathrm{pH}$ range $(6 \cdot 0-9 \cdot 0)$ but growth was inhibited at $\mathrm{pH}$ values below 
Table 2. Cellular fatty acid profiles of strain $\mathrm{PDB}^{\top}$ and the type strains of some Rhodococcus species

\begin{tabular}{|c|c|c|c|c|c|c|}
\hline Fatty acid* & $\begin{array}{l}\text { R. coprophilus } \\
\text { DSM } 43347^{\mathrm{T}}\end{array}$ & $\begin{array}{c}\text { R. rhodnii } \\
\text { DSM } \text { 43336 }^{\mathrm{T}}\end{array}$ & 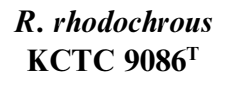 & $\begin{array}{c}R . \text { ruber } \\
\text { DSM 43338 }\end{array}$ & $\begin{array}{c}R . \text { zopfii } \\
\text { DSM 44108 }\end{array}$ & $\begin{array}{l}\text { Strain } \\
\text { PDB9 }^{\mathrm{T}}\end{array}$ \\
\hline \multicolumn{7}{|l|}{ Saturated fatty acids } \\
\hline $\mathrm{C}_{14: 0}$ & $1 \cdot 8$ & $3 \cdot 1$ & $1 \cdot 7$ & $1 \cdot 5$ & $1 \cdot 7$ & $1 \cdot 8$ \\
\hline $\mathrm{C}_{15: 0}^{14: 0}$ & $2 \cdot 7$ & $3 \cdot 3$ & 1.9 & $2 \cdot 9$ & $1 \cdot 0$ & $1 \cdot 0$ \\
\hline $\mathrm{C}_{16: 0}$ & $23 \cdot 1$ & $34 \cdot 3$ & $22 \cdot 7$ & $27 \cdot 4$ & $32 \cdot 7$ & $34 \cdot 0$ \\
\hline $\mathrm{C}_{17: 0}$ & $1 \cdot 8$ & $1 \cdot 4$ & $2 \cdot 8$ & $4 \cdot 3$ & & $3 \cdot 0$ \\
\hline $\mathrm{C}_{18: 0}$ & & $1 \cdot 0$ & 1.9 & $2 \cdot 4$ & $8 \cdot 8$ & $5 \cdot 2$ \\
\hline $\mathrm{C}_{19: 0}$ & & & $2 \cdot 7$ & & $0 \cdot 6$ & $2 \cdot 4$ \\
\hline $\mathrm{C}_{20: 0}$ & & & $5 \cdot 2$ & & $2 \cdot 1$ & $1 \cdot 2$ \\
\hline \multicolumn{7}{|l|}{ Unsaturated fatty acids } \\
\hline $\mathrm{C}_{16: 1} c i s 9$ & $5 \cdot 6$ & & $4 \cdot 1$ & $1 \cdot 2$ & $6 \cdot 6$ & $5 \cdot 8$ \\
\hline $\mathrm{C}_{16: 1} \mathrm{~B} \dagger$ & & & $1 \cdot 0$ & & & $0 \cdot 5$ \\
\hline $\mathrm{C}_{17: 1}^{10.1} \operatorname{cis} 9$ & $1 \cdot 3$ & $2 \cdot 3$ & $1 \cdot 6$ & $4 \cdot 3$ & $1 \cdot 2$ & $1 \cdot 6$ \\
\hline $\mathrm{C}_{18: 1} \operatorname{cis} 9$ & $2 \cdot 4$ & $13 \cdot 7$ & $6 \cdot 0$ & $20 \cdot 7$ & $16 \cdot 5$ & $21 \cdot 6$ \\
\hline $\mathrm{C}_{20: 4}$ cis 5, cis 8, cis 11, cis $14(19 \cdot 395)$ & & & $2 \cdot 4$ & & & \\
\hline $\mathrm{C}_{20: 1} \operatorname{cis} 11$ & & & $0 \cdot 6$ & & $1 \cdot 7$ & \\
\hline \multicolumn{7}{|l|}{ Cyclo fatty acid } \\
\hline $\mathrm{C}_{17: 0}(16 \cdot 889)$ & $1 \cdot 8$ & & & & & \\
\hline \multicolumn{7}{|l|}{ 10-Methyl-fatty acids } \\
\hline $\mathrm{C}_{16: 0}$ & $12 \cdot 5$ & & $5 \cdot 2$ & $0 \cdot 6$ & $2 \cdot 9$ & $1 \cdot 4$ \\
\hline $\mathrm{C}_{17: 0}$ & $4 \cdot 5$ & $2 \cdot 1$ & $2 \cdot 2$ & $1 \cdot 8$ & & $0 \cdot 7$ \\
\hline $\mathrm{C}_{18: 0}$ & $24 \cdot 1$ & $23 \cdot 7$ & $22 \cdot 8$ & $15 \cdot 6$ & $13 \cdot 1$ & $11 \cdot 5$ \\
\hline \multicolumn{7}{|l|}{ Summed features } \\
\hline $4(15 \cdot 858)$ & $16 \cdot 1$ & $15 \cdot 2$ & $14 \cdot 3$ & $15 \cdot 9$ & $9 \cdot 4$ & $8 \cdot 6$ \\
\hline 7 & & & & & $1 \cdot 3$ & \\
\hline 8 & & & $0 \cdot 9$ & $1 \cdot 3$ & & \\
\hline \multicolumn{7}{|l|}{ Unknown fatty acid } \\
\hline$(16 \cdot 918)$ & $2 \cdot 4$ & & & & & \\
\hline
\end{tabular}

* Values in parentheses represent equivalent chain-lengths.

$\dagger$ Double-bond position indicated by a capital letter is unknown.

$\$$ Summed features represent groups of two or three fatty acids that could not be separated by GLC with the MIDI system. Summed feature 4 , iso- $\mathrm{C}_{15: 0} 2-\mathrm{OH}$ and/or $\mathrm{C}_{16: 1}$ trans 9 ; summed feature $7, \mathrm{C}_{18: 1}$ cis $11, \mathrm{C}_{18: 1}$ trans 6 and/or $\mathrm{C}_{18: 1}$ trans 9 ; summed feature 8 , unknown 18.756 and/or $\mathrm{C}_{19: 1}$ cis 10 .

5.0. The optimum $\mathrm{pH}$ for growth was $7 \cdot 5-8 \cdot 5$. Strain $\mathrm{PDB}^{\mathrm{T}}$ grew optimally at temperatures in the range $30-37^{\circ} \mathrm{C}$ and growth occurred at 10 and $45^{\circ} \mathrm{C}$ but not at $50{ }^{\circ} \mathrm{C}$. Growth occurred weakly under anaerobic conditions on TSA. Some other physiological properties of strain PDB9 ${ }^{\mathrm{T}}$ are shown in Table 1 , together with those of the type strains of some Rhodococcus species.

\section{Chemotaxonomic characteristics and DNA base composition}

Strain PDB9 ${ }^{\mathrm{T}}$ contained meso-diaminopimelic acid as the diamino acid and arabinose and galactose as major sugars in the cell wall, which is characteristic of wall chemotype IV sensu Lechevalier \& Lechevalier (1970). The acyl type in the muramic acid of the peptidoglycan was glycolyl. The major isoprenoid quinone found in strain PDB9 ${ }^{\mathrm{T}}$ was dihydrogenated menaquinone with eight isoprene units $\left[\mathrm{MK}-8\left(\mathrm{H}_{2}\right)\right]$. Strain PDB9 ${ }^{\mathrm{T}}$ contained major amounts of the mycolic acids with an overall range of $36-46$ carbon atoms $\left(5 \% \mathrm{C}_{36}, 5 \% \mathrm{C}_{38}\right.$, $18 \% \mathrm{C}_{40}, 29 \% \mathrm{C}_{42}, 27 \% \mathrm{C}_{44}$ and $\left.15 \% \mathrm{C}_{46}\right)$. The cellular fatty acid profile of strain $\mathrm{PDB} 9^{\mathrm{T}}$ was similar to those of the type strains of some Rhodococcus species (Table 2). Strain PDB9 ${ }^{\mathrm{T}}$ contained straightchain saturated, unsaturated and 10-methyl-branched fatty acids and major amounts of $\mathrm{C}_{16: 0}, \mathrm{C}_{18: 1}$ cis 9,10 methyl- $\mathrm{C}_{18: 0}$ (TBSA) (Table 2). Strain PDB9 ${ }^{\mathrm{T}}$ was differentiated from the type strain of $R$. rhodochrous, its phylogenetic neighbour, by the composition of the major fatty acids.

The DNA $\mathrm{G}+\mathrm{C}$ content of strain PDB9 $^{\mathrm{T}}$ was $66 \mathrm{~mol} \%$, a value within the known range for the genus Rhodococcus (Kämpfer et al., 1999; Takeuchi \& Hatano, 1998).

\section{Phylogenetic analysis based on 16S rDNA sequence}

The 16S rDNA sequence of strain PDB9 ${ }^{\mathrm{T}}$, which was directly determined after PCR amplification, was 1477 nucleotides long, which corresponded to the region 


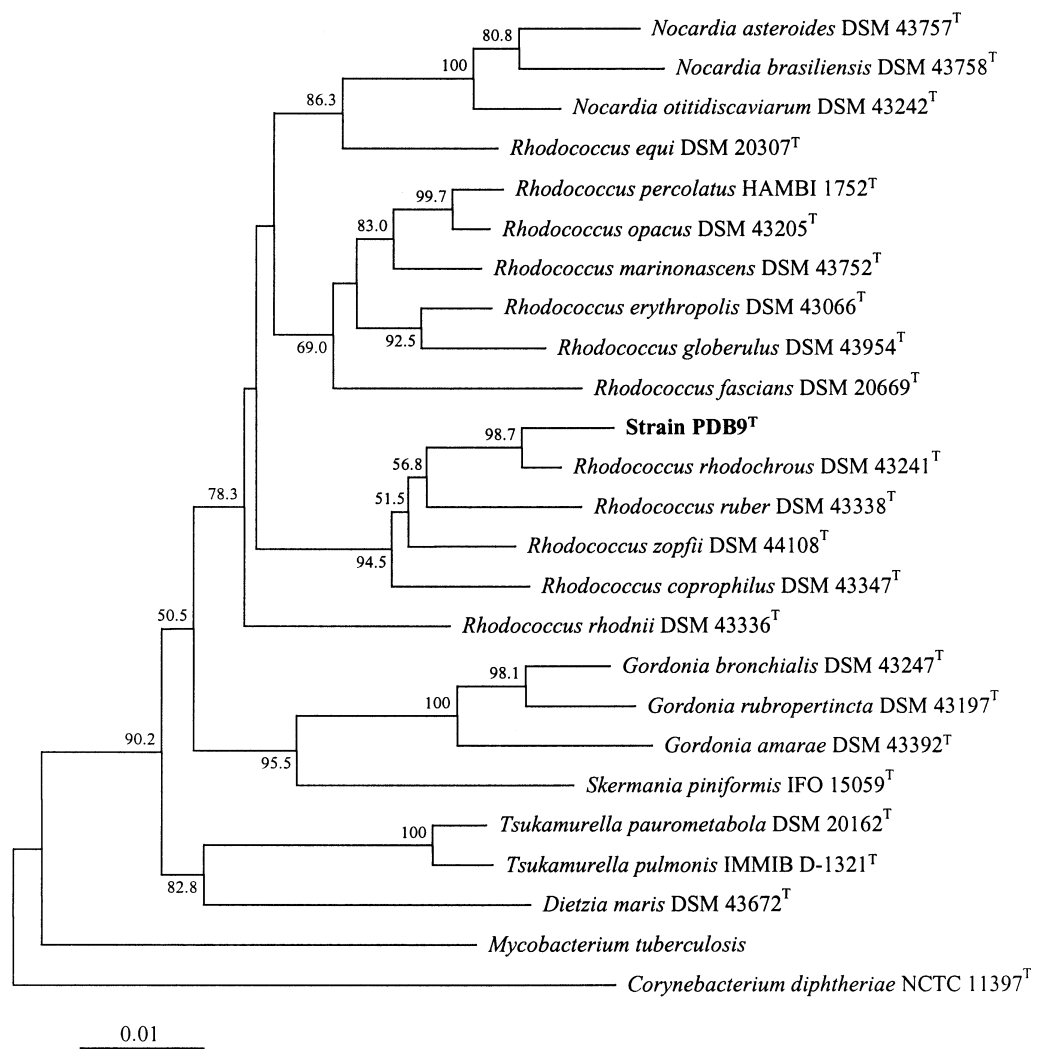

Fig. 1. Phylogenetic tree, based on $16 \mathrm{~S}$ rDNA sequences, showing the positions of strain PDB9 ${ }^{\top}$, Rhodococcus species and representatives of mycolic-acid-containing actinomycete taxa. Bootstrap values (expressed as percentages of 1000 replications) greater than $50 \%$ are shown at the branch points. Bar, 0.01 substitution per nucleotide position.

Table 3. Levels of DNA-DNA relatedness

\begin{tabular}{|c|c|c|}
\hline \multirow[t]{2}{*}{ Strain } & \multicolumn{2}{|c|}{ Percentage reassociation with: } \\
\hline & Strain PDB9 ${ }^{\mathrm{T}}$ & R. rhodochrous KCTC $9086^{\mathrm{T}}$ \\
\hline Strain PDB9 ${ }^{\mathrm{T}}$ & 100 & $48 \cdot 8$ \\
\hline Rhodococcus coprophilus DSM $43347^{\mathrm{T}}$ & $10 \cdot 7$ & $10 \cdot 8$ \\
\hline Rhodococcus rhodnii DSM $43336^{\mathrm{T}}$ & $8 \cdot 3$ & $8 \cdot 4$ \\
\hline Rhodococcus rhodochrous KCTC $9086^{\mathrm{T}}$ & $43 \cdot 3$ & 100 \\
\hline Rhodococcus ruber DSM $43338^{\mathrm{T}}$ & $12 \cdot 9$ & $10 \cdot 8$ \\
\hline Rhodococcus zopfii DSM $44108^{\mathrm{T}}$ & $9 \cdot 6$ & $6 \cdot 2$ \\
\hline
\end{tabular}

( $>96 \%$ ) between positions 28 and 1524 by comparison with Escherichia coli $16 \mathrm{~S}$ rRNA. The $16 \mathrm{~S}$ rDNA sequence of strain PDB9 ${ }^{T}$ was compared with those of Rhodococcus species and the representatives of other mycolic-acid-containing actinomycete genera. This sequence contains all the 'signature' nucleotide characteristic of the family Nocardiaceae according to Stackebrandt et al. (1997). In the tree-based neighbour-joining algorithm, strain PDB9 ${ }^{\mathrm{T}}$ falls within the radiation of the cluster comprising Rhodococcus species, and, in particular, forms a coherent cluster with the type strains of $R$. rhodochrous, R. ruber, $R$. zopfii and $R$. coprophilus (Fig. 1). The formation of this coherent cluster was also confirmed in the trees generated with the maximum-likelihood and maximum-parsimony algorithms. The $16 \mathrm{~S}$ rDNA sequence of strain PDB9 ${ }^{\mathrm{T}}$ showed the highest degree of relatedness with that of R. rhodochrous DSM $43241^{\mathrm{T}}(99 \%$ nucleotide similarity). The $16 \mathrm{~S}$ rDNA sequence similarity between strain $\mathrm{PDB}^{\mathrm{T}}$ and the type strains of other validly described Rhodococcus species are in the range 94.6$97 \cdot 7 \%$

\section{DNA-DNA relatedness}

DNA-DNA hybridization was performed between strain $\mathrm{PDB}^{\mathrm{T}}$ and $R$. rhodochrous $\mathrm{KCTC} 9086^{\mathrm{T}}$ and between the two species and the type strains of $R$. coprophilus, R. ruber, $R$. zopfii and $R$. rhodnii. Strain PDB9 $^{\mathrm{T}}$ exhibited two independent DNA relatedness values of 43.3 and $48.8 \%$ with $R$. rhodochrous KCTC $9086^{\mathrm{T}}$, the closest phylogenetic relative (Table 
3). The levels of DNA-DNA relatedness between strain $\mathrm{PDB}^{\mathrm{T}}$ and the type strains of other Rhodococcus species were $8 \cdot 3-12 \cdot 9 \%$ (Table 3 ).

\section{DISCUSSION}

From the results of the pyridine-degradation tests, strain PDB9 ${ }^{\mathrm{T}}$ was shown to be very useful organism capable of degrading high concentrations of pyridine (up to approx. $3500 \mathrm{mg}^{-1}$ ). This test was also performed with the type strains of all validly described Rhodococcus species. Two species, $R$. opacus DSM $43205^{\mathrm{T}}$ and $R$. percolatus HAMBI $1752^{\mathrm{T}}$, were found to degrade pyridine (albeit at pyrimidine concentrations lower than those degraded by strain $\mathrm{PDB} 9^{\mathrm{T}}$ ), whereas the type strains of other Rhodococcus species could not degrade even the minimum concentration of pyridine.

In view of the combined morphological, chemotaxonomic and phylogenetic data, it is evident that strain PDB9 ${ }^{\mathrm{T}}$ belongs to the genus Rhodococcus. The phylogenetic analysis based on 16S rDNA sequences places strain $\mathrm{PDB}^{\mathrm{T}}$ within the radiation of the cluster enclosing the members of the genus Rhodococcus (Fig. 1). Mycolic-acid-containing actinomycete genera, like most actinomycete taxa, exhibit a good correlation between phylogenetic inference and the results of chemotaxonomic analyses. Accordingly, comparative analysis of chemotaxonomic data are necessary to verify the taxonomic position of strain $\mathrm{PDB} 9^{\mathrm{T}}$ within the mycolic-acid-containing actinomycete genera. Among the mycolic-acid-containing genera, those that have MK-8( $\left.\mathrm{H}_{2}\right)$ as the predominant menaquinone include Corynebacterium, Dietzia and Rhodococcus (Takeuchi \& Hatano, 1998; Kämpfer et al., 1999). Therefore, strain PDB9 ${ }^{\mathrm{T}}$ can be distinguished from the genera Gordonia, Mycobacterium, Nocardia, Skermania and Tsukamurella by the presence of the predominant menaquinone MK- $8\left(\mathrm{H}_{2}\right)$. The genus Williamsia, which has recently been described as a member of the mycolic-acid-containing actinomycetes, contains MK-9 $\left(\mathrm{H}_{2}\right)$ as the only menaquinone (Kämpfer et al., 1999). The acyl type (glycolyl) of the muramic acid of strain PDB9 ${ }^{\mathrm{T}}$ distinguishes this organism from the genera Dietzia and Corynebacterium, the acyl type of which is acetyl (Takeuchi \& Hatano, 1998; Kämpfer et al., 1999). Strain PDB9 ${ }^{\mathrm{T}}$ is also characterized by the presence of mycolic acids that are longer than those of the genera Dietzia $\left(\mathrm{C}_{34}-\mathrm{C}_{38}\right)$ and Corynebacterium $\left(\mathrm{C}_{22}-\mathrm{C}_{36}\right)$ (Takeuchi \& Hatano, 1998; Kämpfer et al., 1999). Chemotaxonomic markers, including the predominant menaquinone type, the acyl type, the lengths of mycolic acids and the fatty acid profile, confirm the taxonomic position of strain PDB9 ${ }^{\mathrm{T}}$ within the genus Rhodococcus, a possible classification based on phylogenetic inference.

The colonial morphology of strain PDB9 $9^{\mathrm{T}}$ is differentiated from those of the type strains of all of the valid
Rhodococcus species because it has irregularly round wrinkles. Strain PDB9 ${ }^{\mathrm{T}}$ shows close phylogenetic relatedness with $R$. rhodochrous, $R$. ruber, $R$. zopfii and $R$. coprophilus (Fig. 1). In particular, the highest level of phylogenetic relatedness was found in the relationship between strain PDB9 ${ }^{\mathrm{T}}$ and $R$. rhodochrous DSM $43241^{\mathrm{T}}$ (99\% 16S rDNA similarity; Fig. 1). The levels of $16 \mathrm{~S}$ rDNA similarity between strain PDB9 ${ }^{\mathrm{T}}$ and the type strains of other Rhodococcus species, except for the above-mentioned Rhodococcus species, are below $96.3 \%$. This indicates that strain PDB9 ${ }^{\mathrm{T}}$ is a different species with respect to other Rhodococcus species except $R$. rhodochrous, R. ruber, $R$. zopfii and $R$. coprophilus (Stackebrandt \& Goebel, 1994). Strain PDB $9^{\mathrm{T}}$ was compared with the type strains of $R$. rhodochrous, $R$. ruber, $R$. zopfii, $R$. coprophilus and $R$. rhodnii through phenotypic analysis and DNA-DNA relatedness. As shown in Table 1, strain PDB9 ${ }^{\mathrm{T}}$ showed physiological properties that are distinguishable from those of the type strains of the five Rhodococcus species. In particular, the ability of strain $\mathrm{PDB}^{\mathrm{T}}$ to degrade pyridine was not found in the type strains of other Rhodococcus species, with the exception of $R$. opacus and $R$. percolatus, or in the type strains of $R$. rhodochrous, $R$. ruber, $R$. zopfii, $R$. coprophilus and $R$. rhodnii. The fatty acid profile of strain $\mathrm{PDB} 9^{\mathrm{T}}$ is similar to those of the type strains of Rhodococcus species tested but shows differences with respect to the type strains of $R$. rhodochrous and $R$. coprophilus in terms of the composition of $\mathrm{C}_{16: 0}, \mathrm{C}_{18: 1}$ cis 9,10 methyl- $\mathrm{C}_{18: 0}$ (TBSA) (Table 2). The levels of DNADNA relatedness provide decisive evidence that strain $\mathrm{PDB}^{\mathrm{T}}$ is genetically different from the Rhodococcus species tested (Table 3) (Wayne et al., 1987). Thus, the differences in some phenotypic characteristics, as well as its phylogenetic and genetic distinctiveness, distinguish strain $\mathrm{PDB}^{\mathrm{T}}$ from the Rhodococcus species described previously.

On the basis of the data described above, strain PDB9 ${ }^{\mathrm{T}}$ should be assigned to the genus Rhodococcus as a new species, for which we propose the name, $R$. pyridinivorans sp. nov. The properties of the new species are summarized below.

\section{Description of Rhodococcus pyridinivorans sp. nov.}

Rhodococcus pyridinivorans (py.ri.di.ni.vo'rans. M.L. n. pyridin pyridine; L. v. vorare to devour; N.L. adj. pyridinivorans pyridine-devouring).

The cells are non-spore-forming, non-motile and Gram-positive, but are Gram-variable in old cultures. Substrate mycelia that are on the surface and penetrate into the agar media are visible and fragment into short rod-to-coccus elements. The cells are rods and branched filaments during the early growth phase and then fragment into short rods or cocci. Colonies are light orange in colour, opaque and raised with slightly irregular edges on TSA. Colonies have irregularly round wrinkles. Grows well over a broad $\mathrm{pH}$ range 
$(6 \cdot 0-9 \cdot 0)$; the optimal $\mathrm{pH}$ range is $7 \cdot 5-8 \cdot 5$. Grows optimally at $30-37^{\circ} \mathrm{C}$; growth occurs at 10 and $45^{\circ} \mathrm{C}$ but does not occur at $50{ }^{\circ} \mathrm{C}$. Catalase- and ureasepositive. Oxidase- and DNase-negative. Arbutin, aesculin, Tween 80, tyrosine and urea are hydrolysed. Casein, hypoxanthine, starch and xanthine are not hydrolysed. Nitrate is reduced to nitrite. VogesProskauer and methyl red reactions are negative. $\mathrm{H}_{2} \mathrm{~S}$ is produced. Acid is produced from D-fructose, glycerol, D-mannitol, D-mannose, D-ribose, salicin, D-sorbitol and starch. No acid is produced from Larabinose, D-cellobiose, D-galactose, D-glucose, inulin, lactose, maltose, D-raffinose, L-rhamnose, trehalose or D-xylose. Acetate, citrate, fumarate and succinate are utilized. Benzoate, formate, hippurate and tartrate are not utilized. Degrades pyridine. The cell wall contains meso-diaminopimelic acid, arabinose and galactose (wall chemotype IV). The predominant menaquinone is $\mathrm{MK}-8\left(\mathrm{H}_{2}\right)$. The major fatty acids are $\mathrm{C}_{16: 0}, \mathrm{C}_{18: 1}$ cis9, 10-methyl- $\mathrm{C}_{18: 0}$ (TBSA). Mycolic acids with 36-46 carbon atoms are present. The $\mathrm{G}+\mathrm{C}$ content of the DNA is $66 \mathrm{~mol} \%$ (as determined by HPLC). The type strain is strain $\mathrm{PDB}^{\mathrm{T}}$, which has been deposited in the Korean Collection for Type Cultures as KCTC 0647BP ${ }^{\mathrm{T}}$ and in the Korean Culture Centre of Microorganisms as KCCM $80005^{\mathrm{T}}$.

\section{ACKNOWLEDGEMENTS}

This work was supported by grants HS2321 and HS2701 from the Ministry of Science and Technology (MOST) of the Republic of Korea. We are grateful to the DSMZ for analysing the mycolic acids.

\section{REFERENCES}

Briglia, M., Rainey, F. A., Stackebrandt, E., Schraa, G. \& SalkinojaSalonen, M. S. (1996). Rhodococcus percolatus sp. nov., a bacterium degrading 2,4,6-trichlorophenol. Int J Syst Bacteriol 46, 23-30.

Brinkmann, U. \& Babel, W. (1996). Simultaneous utilization of pyridine and fructose by Rhodococcus opacus UFZ B 408 without an external nitrogen source. Appl Microbiol Biotechnol 45, 217-223.

Cowan, S. T. \& Steel, K. J. (1965). Manual for the Identification of Medical Bacteria. London: Cambridge University Press.

Ezaki, T., Hashimoto, Y. \& Yabuuchi, E. (1989). Fluorometric deoxyribonucleic acid-deoxyribonucleic acid hybridization in microdilution wells as an alternative to membrane filter hybridization in which radioisotopes are used to determine genetic relatedness among bacterial strains. Int $J$ Syst Bacteriol 39, 224-229.

Felsenstein, J. (1981). Evolutionary trees from DNA sequences: a maximum likelihood approach. J Mol Evol 17, 368-376.

Felsenstein, J. (1993). PHYLIP (Phylogeny Inference Package), version 3.5. Seattle: University of Washington.

Finnerty, W. R. (1992). The biology and genetics of the genus Rhodococcus. Annu Rev Microbiol 46, 193-218.

Goodfellow, M. (1989). Genus Rhodococcus Zopf 1891, 28 ${ }^{\mathrm{AL}}$. In Bergey's Manual of Systematic Bacteriology, vol. 4, pp. 2362-2371. Edited by S. T. Williams, M. E. Sharpe \& J. G. Holt. Baltimore: Williams \& Wilkins.
Houghton, C. \& Cain, R. B. (1972). Microbial metabolism of the pyridine ring. Biochem $J$ 130, 879-893.

Hugh, R. \& Leifson, E. (1953). The taxonomic significance of fermentative versus oxidative metabolism of carbohydrates by various Gram negative bacteria. J Bacteriol 66, 24-26.

Jori, A., Calamari, D., Cattabeni, E., Domenico, A. D., Galli, C. L., Galli, E. \& Silano, V. (1983). Ecotoxicological profile of pyridine. Ecotoxicol Environ Safety 7, 251-275.

Jukes, T. H. \& Cantor, C. R. (1969). Evolution of protein molecules. In Mammalian Protein Metabolism, vol. 3, pp. 21-132. Edited by H. N. Munro. New York: Academic Press.

Kämpfer, P., Andersson, M. A., Rainey, F. A., Kroppenstedt, R. M. \& Salkinoja-Salonen, M. (1999). Williamsia muralis gen. nov., sp. nov., isolated from the indoor environment of a children's day care centre. Int J Syst Bacteriol 49, 681-687.

Kluge, A. G. \& Farris, F. S. (1969). Quantitative phyletics and the evolution of anurans. Syst Zool 18, 1-32.

Komagata, K. \& Suzuki, K.-I. (1987). Lipids and cell-wall analysis in bacterial systematics. Methods Microbiol 19, 161-203.

Kurup, V. P. \& Fink, J. N. (1975). A scheme for the identification of thermophilic actinomycetes associated with hypersensitivity pneumonitis. J Clin Microbiol 2, 55-61.

Lanyi, B. (1987). Classical and rapid identification methods for medically important bacteria. Methods Microbiol 19, 1-67.

Lechevalier, M. P. \& Lechevalier, H. A. (1970). A critical evaluation of the genera of aerobic actinomycetes. In The Actinomycetales, pp. 393-405. Edited by H. Prauser. Jena: Gustav Fischer.

Lee, S.-T., Rhee, S.-K. \& Lee, G. M. (1994). Biodegradation of pyridine by freely suspended and immobilized Pimelobacter $\mathrm{sp}$. Appl Microbiol Biotechnol 41, 652-657.

Leenheer, J. A. \& Stuber, H. A. (1981). Migration through soil of organic solutes in an oil-shale process water. Environ Sci Technol 15, 1467-1475.

Peczynska-Czoch, W. \& Mordarski, M. (1984). Transformation of xenobiotics. In The Biology of the Actinomycetes, pp. 287-336. Edited by M. Goodfellow, M. Mordarski \& S. T. Williams. London: Academic Press.

Rast, H. G., Engelhardt, G. \& Wallnoefer, P. R. (1980). Degradation of aromatic compounds in the actinomycete genus Rhodococcus. FEMS Microbiol Lett 7, 1-7.

Rogall, T., Wolters, J., Flohr, T. \& Böttger, E. C. (1990). Towards a phylogeny and definition of species at the molecular level within the genus Mycobacterium. Int J Syst Bacteriol 40, 323-330.

Saddler, G. S., Tavecchia, P., Lociuro, S., Zanol, M., Colombo, L. \& Selva, E. (1991). Analysis of madurose and other actinomycete whole cell sugars by gas chromatography. J Microbiol Methods 14, 185-191.

Saitou, N. \& Nei, M. (1987). The neighbor-joining method: a new method for reconstructing phylogenetic trees. Mol Biol Evol 4, 406-425.

Shukla, O. P. \& Kaul, S. M. (1974). A constitutive pyridine degrading system in Corynebacterium sp. Indian $J$ Biochem Biophysics 11, 201-207.

Shukla, O. P. \& Kaul, S. M. (1975). Succinate semialdehyde, an intermediate in the degradation of pyridine by Brevibacterium sp. Indian J Biochem Biophysics 12, 326-330.

Sims, G. K. \& O'Loughlin, E. J. (1989). Degradation of pyridine in the environment. CRC Crit Rev Environ Control 19, 309-340.

Stackebrandt, E. \& Goebel, B. M. (1994). Taxonomic note: a place for DNA-DNA reassociation and $16 \mathrm{~S}$ rRNA sequence 
analysis in the present species definition in bacteriology. Int $J$ Syst Bacteriol 44, 846-849.

Stackebrandt, E., Rainey, F. A. \& Ward-Rainey, N. L. (1997). Proposal for a new hierarchic classification system, Actinobacteria classis nov. Int J Syst Bacteriol 47, 479-491.

Stuermer, D. H., Ng, D. J. \& Morris, C. J. (1982). Organic contaminants in groundwater near an underground coal gasification site in northeastern Wyoming. Environ Sci Technol 16, 582-587.

Takeuchi, M. \& Hatano, K. (1998). Gordonia rhizosphera sp. nov. isolated from the mangrove rhizosphere. Int J Syst Bacteriol $\mathbf{4 8}$, 907-912.

Tamaoka, J. \& Komagata, K. (1984). Determination of DNA base composition by reverse-phase high-performance liquid chromatography. FEMS Microbiol Lett 25, 125-128.

Thompson, J. D., Higgins, D. G. \& Gibson, T. J. (1994). CLUSTAL $\mathrm{W}$ : improving the sensitivity of progressive multiple sequence alignment through sequence weighting, position-specific gap penalties and weight matrix choice. Nucleic Acids Res 22. 4673-4680.

Uchida, K. \& Aida, K. (1977). Acyl type of bacterial cell wall: its simple identification by colorimetric method. J Gen Appl Microbiol 23, 249-260.

Warhurst, A. M. \& Fewson, C. A. (1994). Biotransformations catalyzed by the genus Rhodococcus. Crit Rev Biotechnol $\mathbf{1 4}$ 29-73.
Watson, G. K. \& Cain, R. B. (1975). Microbial metabolism of the pyridine ring. Biochem $J$ 146, 157-172.

Wayne, L. G., Brenner, D. J., Colwell, R. R. \& 9 other authors (1987). International Committee on Systematic Bacteriology. Report of the ad hoc committee on reconciliation of approaches to bacterial systematics. Int J Syst Bacteriol 37, 463-464.

Yoon, J.-H., Kim, H., Kim, S.-B., Kim, H.-J., Kim, W. Y., Lee, S. T., Goodfellow, M. \& Park, Y.-H. (1996). Identification of Saccharomonospora strains by the use of genomic DNA fragments and rRNA gene probes. Int J Syst Bacteriol 46, 502-505.

Yoon, J.-H., Rhee, S.-K., Lee, J.-S., Park, Y.-H. \& Lee, S. T. (1997). Nocardioides pyridinolyticus sp. nov., a pyridine-degrading bacterium isolated from the oxic zone of an oil shale column. Int J Syst Bacteriol 47, 933-938.

Yoon, J.-H., Lee, S. T. \& Park, Y.-H. (1998). Inter- and intraspecific phylogenetic analysis of the genus Nocardioides and related taxa based on 16S rDNA sequences. Int J Syst Bacteriol 48, 187-194.

Yoon, J.-H., Cho, Y.-G., Lee, S. T., Suzuki, K.-I., Nakase, T. \& Park, Y.-H. (1999). Nocardioides nitrophenolicus sp. nov., a $p$ nitrophenol-degrading bacterium. Int $J$ Syst Bacteriol 49, 675-680.

Yoon, J.-H., Lee, J. J., Kang, S.-S., Takeuchi, M., Shin, Y. K., Lee, S. T., Kang, K. H. \& Park, Y.-H. (2000). Gordonia nitida sp. nov., a bacterium that degrades 3-ethylpyridine and 3-methylpyridine. Int J Syst Evol Microbiol 50, 1203-1210. 